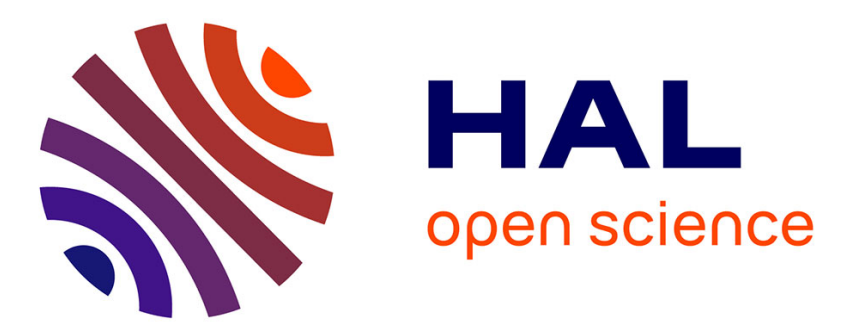

\title{
Bridging the Gap: Bone Tools as Markers of Continuity between Aceramic (Khirokitia Culture) and Ceramic Neolithic (Sotira Culture) in Cyprus (7th-5th millennia cal. BC)
}

Alexandra Legrand-Pineau

\section{To cite this version:}

Alexandra Legrand-Pineau. Bridging the Gap: Bone Tools as Markers of Continuity between Aceramic (Khirokitia Culture) and Ceramic Neolithic (Sotira Culture) in Cyprus (7th-5th millennia cal. BC). Paléorient, 2009, 35 (2), pp.113-123. 10.3406/paleo.2009.5302 . halshs-01562080

\author{
HAL Id: halshs-01562080 \\ https://shs.hal.science/halshs-01562080
}

Submitted on 19 Jul 2017

HAL is a multi-disciplinary open access archive for the deposit and dissemination of scientific research documents, whether they are published or not. The documents may come from teaching and research institutions in France or abroad, or from public or private research centers.
L'archive ouverte pluridisciplinaire HAL, est destinée au dépôt et à la diffusion de documents scientifiques de niveau recherche, publiés ou non, émanant des établissements d'enseignement et de recherche français ou étrangers, des laboratoires publics ou privés. 


\title{
BRIDGING THE GAP: BONE TOOLS AS MARKERS OF CONTINUITY BETWEEN ACERAMIC (KHIROKITIA CULTURE) AND CERAMIC NEOLITHIC (SOTIRA CULTURE) IN CYPRUS (7th-5th MILLENNIA CAL. BC)
}

\author{
A. LEGRAND-PINEAU
}

\begin{abstract}
Recent advances in the study of the Prehistory of Cyprus have greatly increased our knowledge of the beginning of the Neolithic in the island. However, we still have little understanding of the origin of the Ceramic Neolithic-a period separated from the Aceramic by a gap of a thousand years. New evidence yielded by the technological study of the bone industry from the site of Khirokitia suggests a chronological continuity across both occupations. The Cypriot Ceramic Neolithic period may well be the results of a local evolution, as has already been proposed.
\end{abstract}

Résumé: Les recherches conduites à Chypre ces dernières années ont renouvelé la connaissance sur les débuts du Néolithique dans l'île. Toutefois, l'origine du Néolithique céramique qui y apparaît au cours du Ve millénaire av. J.-C., après un hiatus d'environ 1000 ans, pose encore bien des interrogations. L'étude technologique de l'industrie osseuse de Khirokitia fournit des éléments nouveaux en faveur d'une continuité chronologique entre le Néolithique pré-céramique et le Néolithique céramique. L'origine du Néolithique céramique à Chypre pourrait résulter d'une évolution locale comme cela avait été proposé précédemment.

Keywords: Cyprus; Aceramic Neolithic; Ceramic Neolithic; Bone Industry.

Mots-clés: Chypre; Néolithique pré-céramique; Néolithique céramique; Industrie osseuse.

\section{CHRONOLOGICAL AND CULTURAL CONTEXT}

The Aceramic Neolithic period, or Khirokitia Culture in Cyprus (7th-first half of the 6th millennia BC), is found in several villages, which included Khirokitia, Cape AndreasKastros, Klepini-Troulli, Kholetria-Ortos, Petra tou Limniti, and Kataliondas-Kourvellos (fig. 1, table 1). Extensive archaeological research conducted on these sites has uncovered certain features that can now be considered characteristic of this period. ${ }^{1}$ For example, most of these settlements are located on hills and promontories, while others are naturally protected. Consideration of the domestic architecture indicates that the architectural units have a circular ground plan and not a rectangular one as seen in most contemporary villages in the Near East. Small stone objects such as beads, pendants, and stone vessels (these can be divided into two categories-coarse or fine), are particularly characteristic of the Khirokitia culture.

1. LE BRUN, 1981, 1984, 1989 and 1994. 


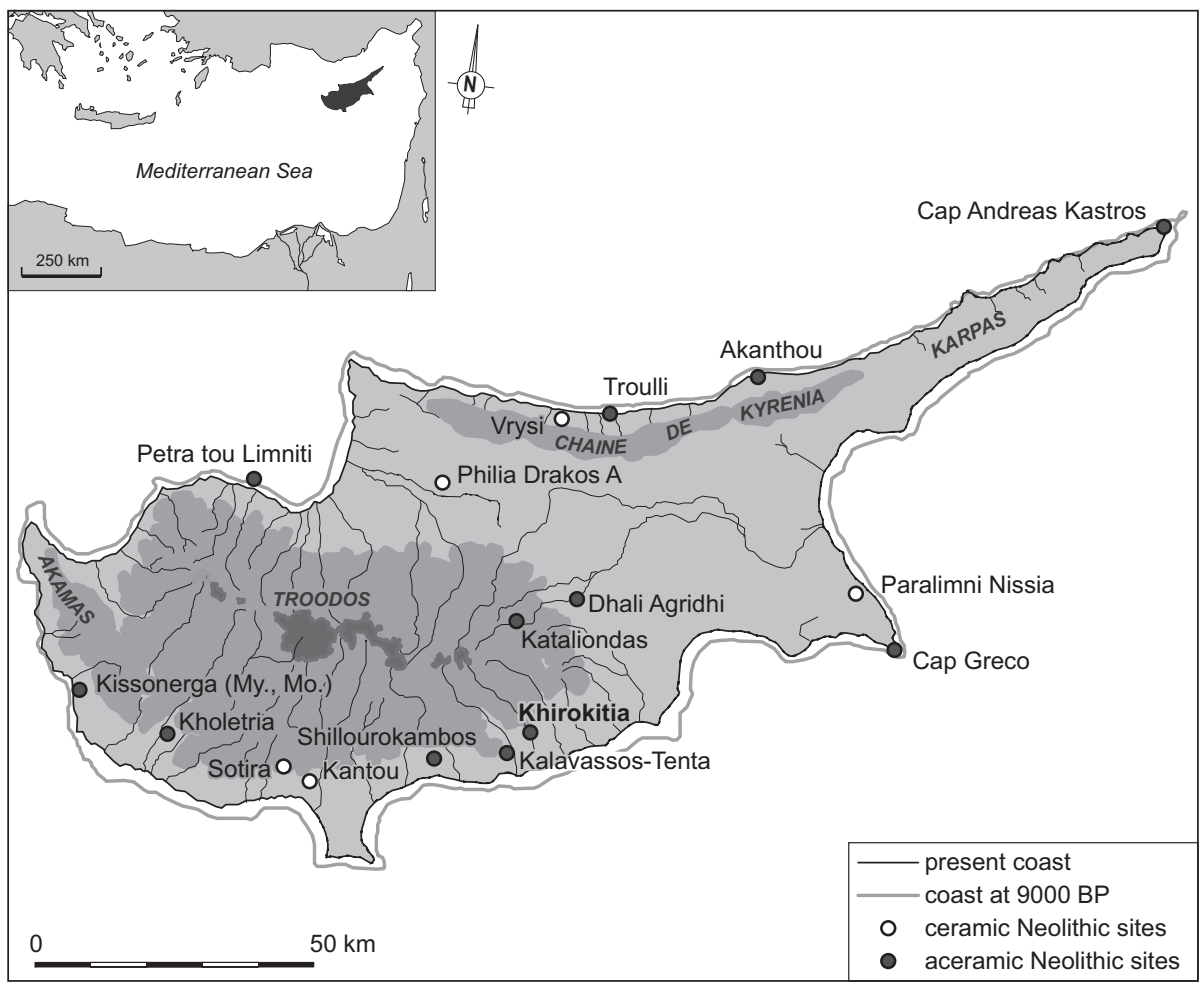

Fig. 1 - Map of Cyprus (adapted from GOMEZ and PEASE, 1992).

The economy is based on the exploitation of four main species of large mammals: fallow deer, sheep, goats, and pigs, and the anthracological data indicate a broad-based exploitation of the environment.

For reasons that are not completely understood, the Khirokitia Culture collapsed during the first half of the 6th millennium. Several hypotheses have been proposed to explain its demise: some of the causes that have been suggested include a significant decrease in the island's population, a shift from a largely sedentary farming and herding subsistence base towards a more mobile way of life that relied on hunting deer, ${ }^{2}$ or very dry environmental conditions that developed around $5600 \mathrm{BC}$, which may have had a negative impact on sedentary farming communities. ${ }^{3}$

In the first half of the 5th millennium, the Ceramic Neolithic period (Sotira Culture), which was characterized by the emergence of pottery, appeared on the island (table 2). A time

2. STANLEY-PRICE, 1977.

3. HELD, 1992 and 1993. period from 500 to 1,000 years separates this era from the Aceramic Neolithic period. ${ }^{4}$ J. Clarke, ${ }^{5}$ refers to this gap as:

"largely a problem in chrono-typological sequence, caused in the main by three factors: 1/ site visibility; 2/ an apparent absence of cultural material from this period and $3 /$ the very small number of radiocarbon determinations ${ }^{6}(\ldots)$ for the very end of the Khirokitian or the very beginning of the Late Neolithic period."

This lack of data is part of the debate on the origin of the Ceramic Neolithic period. Some authors suggest that this population was the result of a second colonization from the mainland, while others support a local evolution.? Archaeological data provided by the study of some Aceramic Neolithic sites that

4. ClARKE et al., 2007: 34; KNAPP et al., 1994: 407; PELTENBURG et al., 2003: 86.

5. CLARKE et al., 2007: 34.

6. The controversial site of Dhali-Agridhi provides a radiometric date of $5287 \pm 399$ BC (5600-4950 BC) which partly fills the gap (CLARKE, 2001; LEHAVY, 1989).

7. KNAPP et al., 1994; STANLEY-PRICE, 1977; TODD, 1985; WATKINS, 1973. 
Table 1 - Aceramic Neolithic sites-Radiocarbon dating (from CLARKE et al., 2007: fig. 2.2, 17).

\begin{tabular}{|c|c|c|c|c|c|c|}
\hline Site & Lab-Ref & Age BP & Material & Deposit/Phasing & $1 \sigma$ & $2 \sigma$ \\
\hline K-Tenta 21 & P-2975 & $6970 \pm 310$ & charcoal & F11C P3 or later & $6250-5550 \mathrm{BC}$ & $6500-5300 \mathrm{BC}$ \\
\hline K-Tenta 23 & P-2977 & $6580 \pm 290$ & charcoal & Fill of a pit (P2) & $5800-5200 \mathrm{BC}$ & $6100-4800 \mathrm{BC}$ \\
\hline K-Tenta 11 & P-2781 & $6300 \pm 80$ & charcoal & Hearth in open area & $5470-5080 \mathrm{BC}$ & $5470-5050 \mathrm{BC}$ \\
\hline K-Tenta 1 & P-2549 & $5630 \pm 260$ & charcoal & Fill of a pit & $4800-4150$ BC & $5300-3800 \mathrm{BC}$ \\
\hline C. Andreas & Paris? & $6760 \pm 140$ & & & $5790-5530 \mathrm{BC}$ & $6000-5450 \mathrm{BC}$ \\
\hline C. Andreas & Paris? & $6275 \pm 105$ & & & $5370-5050 \mathrm{BC}$ & $5480-4990 \mathrm{BC}$ \\
\hline C. Andreas & MC-803 & $6140 \pm 200$ & charcoal & Level V & $5310-4840 \mathrm{BC}$ & $5500-4600 \mathrm{BC}$ \\
\hline Khirokitia & Ly-3716 & $7000 \pm 150$ & charcoal & Level C & $6010-5730 \mathrm{BC}$ & $6250-5600 \mathrm{BC}$ \\
\hline Khirokitia & Ly-4306 & $6310 \pm 170$ & charcoal & Level F & $5470-5060 \mathrm{BC}$ & $5650-4800 \mathrm{BC}$ \\
\hline Khirokitia & Ly-4309 & $6230 \pm 160$ & charcoal & Level G & $5370-4490 \mathrm{BC}$ & $5500-4750 \mathrm{BC}$ \\
\hline K-Ortos & Beta-56889 & $6450 \pm 230$ & bone & & $5650-5050 \mathrm{BC}$ & $5800-4800 \mathrm{BC}$ \\
\hline
\end{tabular}

Table 2 - Ceramic Neolithic sites-Radiocarbon dating (from CLARKE et al., 2007: fig. 2.3, 18).

\begin{tabular}{|c|c|c|c|c|c|c|}
\hline Site & Lab-Ref & Age BP & Material & Deposit/Phasing & $1 \sigma$ & $2 \sigma$ \\
\hline Vrysi 1 & BM-847 & $5389 \pm 53$ & charcoal & House 7 floor $4 b$ (Early) & $4340-4080 \mathrm{BC}$ & $4350-4050 \mathrm{BC}$ \\
\hline Vrysi 2 & BM-846 & $5372 \pm 92$ & charcoal & House 4B floor 8 (Early) & $4330-4060 \mathrm{BC}$ & $4360-3980 \mathrm{BC}$ \\
\hline Vrysi 3 & BM-845 & $5360 \pm 57$ & charcoal & House 4A floor 5 (Ea/Mid) & $4330-4070 \mathrm{BC}$ & $4330-4040 \mathrm{BC}$ \\
\hline Vrysi 4 & Birm-182 & $5825 \pm 145$ & charcoal & (Middle) & $4850-4500 \mathrm{BC}$ & $5050-4350 \mathrm{BC}$ \\
\hline Vrysi 5 & Birm-337 & $5740 \pm 140$ & charcoal & (Middle) & $4770-4440 \mathrm{BC}$ & $4950-4300 \mathrm{BC}$ \\
\hline Vrysi 6 & GU-522 & $5420 \pm 80$ & charcoal & House 2A floor 3 (Middle) & $4350-4150 \mathrm{BC}$ & $4460-4040 \mathrm{BC}$ \\
\hline Vrysi 7 & BM-843 & $5355 \pm 67$ & charcoal & House 2A floor 4 (Middle) & $4320-4040 \mathrm{BC}$ & $4340-4000 \mathrm{BC}$ \\
\hline Vrysi 8 & GU-523 & $5340 \pm 95$ & charcoal & House 2A floor 4 (Middle) & $4320-4050 \mathrm{BC}$ & $4350-3970 \mathrm{BC}$ \\
\hline Vrysi 9 & BM-848 & $5330 \pm 57$ & charcoal & Passage B east 3.4 (Middle) & $4240-4050 \mathrm{BC}$ & $4330-3990 \mathrm{BC}$ \\
\hline Vrysi 10 & BM-844 & $5275 \pm 47$ & charcoal & House 2B floor 8 (Middle) & $4230-3990 \mathrm{BC}$ & $4240-3980 \mathrm{BC}$ \\
\hline Vrysi 11 & GU-524 & $5255 \pm 120$ & charcoal & House 1 floor 2 (Middle) & $4240-3960 \mathrm{BC}$ & $4350-3750 \mathrm{BC}$ \\
\hline Vrysi 12 & GU-1459 & $5210 \pm 85$ & charcoal & (Middle) & $4230-3950 \mathrm{BC}$ & $4260-3790 \mathrm{BC}$ \\
\hline Vrysi 13 & BM-1908R & $5360 \pm 110$ & charcoal & (Middle) & $4330-4050 \mathrm{BC}$ & $4450-3960 \mathrm{BC}$ \\
\hline Vrysi 14 & GU-521 & $3105 \pm 130$ & charcoal & Passage A floor 5 (Middle) & $1520-1130 \mathrm{BC}$ & $1700-1000 \mathrm{BC}$ \\
\hline Vrysi 15 & BM-849 & $5224 \pm 78$ & charcoal & Area 5D (Mid/Late) & $4220-3960 \mathrm{BC}$ & $4250-3800 \mathrm{BC}$ \\
\hline Vrysi 16 & BM-1907R & $5290 \pm 100$ & charcoal & (Late) & $4240-3990 \mathrm{BC}$ & $4350-3800 \mathrm{BC}$ \\
\hline Vrysi 17 & BM-1906R & $5360 \pm 120$ & charcoal & (Late) & $4330-4050 \mathrm{BC}$ & $4450-3950 \mathrm{BC}$ \\
\hline Dhali 1 & GX-2847A & $6415 \pm 310$ & charred bone & Concentration A & $5650-5000 \mathrm{BC}$ & $6000-4600 \mathrm{BC}$ \\
\hline Dhali 2 & P-2769 & $5700 \pm 100$ & charred bone & Concentration A & $4690-4450 \mathrm{BC}$ & $4780-4340 \mathrm{BC}$ \\
\hline Sotira & St-337 & $5460 \pm 110$ & charcoal & Hut 29 (Phase 1) & $4450-4080 \mathrm{BC}$ & $4550-4000 \mathrm{BC}$ \\
\hline Sotira & St-350 & $5150 \pm 130$ & charcoal & Hut 12 (Unknown) & $4230-3780 \mathrm{BC}$ & $4350-3650 \mathrm{BC}$ \\
\hline Kantou & & $6270 \pm 60$ & charcoal & Phase 1 & $5320-5070 \mathrm{BC}$ & $5360-5050 \mathrm{BC}$ \\
\hline Kantou & & $5135 \pm 60$ & charcoal & Phase IV & $4040-3800 \mathrm{BC}$ & $4060-3770 \mathrm{BC}$ \\
\hline Philia & Birm-72 & $5720 \pm 100$ & carbon & Phase 3 & $4690-4460 \mathrm{BC}$ & $4780-4360 \mathrm{BC}$ \\
\hline
\end{tabular}


were reoccupied during the Ceramic Neolithic period, including Parekklisha-Shillourokambos, Kalavasos-Tenta, PhiliaDrakos, and Khirokitia, as well as new settlements like Ayios Epiktitos-Vrysi, Sotira-Teppes, Kantou-Kouphovounos, and Paralimni-Nissia, provide us with a more precise idea of the transition. Thus, several similarities between the Aceramic and Ceramic Neolithic periods stand out. For example, the same features in site location and in the construction of walls as village borders have been observed in both Aceramic and Ceramic Neolithic sites. The economy is based on the exploitation of the same animal species, and the chipped and ground stone industries as well as the manufacture of the stone vessels have the same features. ${ }^{8}$ Therefore, it is more likely that the Ceramic Neolithic period could represent a local transition as argued by T. Watkins, even if changes are noticeable in the complexity of architectural arrangements and burial practices.

The bone tool industry has not yet been examined with regard to the question of chronological continuity. How did the bone tool production evolve within the Aceramic Neolithic occupation? How does the development or the introduction to the island of a new culture appear in the bone-tool industry? Do the bone tools show evidence of a technical tradition? Or are they based on a dynamic evolution punctuated by innovations? In order to gather new data on the transition between the 6th and the 5th millennia and to examine the question of chronological continuity versus discontinuity in the bone industry, the Khirokitia bone-tool industry was studied. ${ }^{9}$ Indeed, it offers a good starting point for this research since both occupations are identified in the site, and it has the richest industry of the Neolithic period in Cyprus. A total of 2,317 bone and antler artifacts and specially pointed tools (96\% of points and needles) have been excavated.

The village of Khirokitia is 6 kilometers north of the southern coastline. Approximately $4,000 \mathrm{~m}^{2}$ of the site were excavated out of a total surface area estimated to be 2.5 hect$\operatorname{ares}^{10}$ (fig. 5a). A first occupation (eastern sector) with nine architectural levels (from Level J to Level A), ${ }^{11}$ and a second occupation (western sector) with three levels (from Level III to Level I) have been identified (fig. 5b-c). Both occupations are

8. Dikaios, 1961; KARAgeORGHIS, 1990; LE BRUN, 1996 and 2000; LEGGe, 1982; PeltenburG, 1979 and 1982; ŞEVKetoĞLU, 2000; STANLEY-PRICE, 1979; WATKINS, 1971.

9. LEGRAND, 2007.

10. Hesse et Renimel, 1978; Le BRun et DaUne-Le Brun, 2003. Cf. Le BRUN et DAUNE-LE BRUN in this volume, p. 69-78.

11. The excavation campaign of 2005 has revealed two additional levels (Levels $\mathbf{J}$ and $\mathrm{H}$ ) earlier than Level $\mathrm{G}$ considered as the earliest one. The material collected in these levels has not been studied in this work.
Table 3 - Bone tools distribution by levels.

\begin{tabular}{|c|c|c|c|c|}
\cline { 2 - 5 } \multicolumn{1}{c|}{} & Sectors & Levels & N & \% \\
\hline \multirow{2}{*}{$\begin{array}{l}\text { Aceramic } \\
\text { Neolithic }\end{array}$} & Eastern sector & G/F/E & 50 & 4 \\
\cline { 3 - 5 } & & B & 455 & 36 \\
\cline { 2 - 5 } & Western sector & II & 684 & 55 \\
\hline Ceramic Neolithic & & 2 & 66 & 5 \\
\hline \multicolumn{1}{c|}{ TotAL } & & & $\mathbf{1 , 2 5 5}$ & 100 \\
\hline
\end{tabular}

dated to the Aceramic Neolithic period. The excavated area is partly covered by a layer-Layer 2-that contains architectural elements and ceramic sherds, and evidence of the reoccupation of the site during the Ceramic Neolithic period..$^{12}$ Most of the bone tools derive from the Aceramic Neolithic levels; with only $6 \%$ being derived from the Ceramic Neolithic occupation (Layer 2). Within the Aceramic Neolithic occupation, the bone-tool industry is homogeneously distributed between the eastern sector (45\%) and the western sector (48\%), despite the different excavated surfaces: $470 \mathrm{~m}^{2}$ and $800 \mathrm{~m}^{2}$ respectively. However, a differential distribution of industry by architectural levels is observed. Indeed, Levels B (eastern sector) and II (western sector) are the richest in bone tools. This can be explained by the fact that the excavated zone is larger than in the other levels: $200 \mathrm{~m}^{2}$ excavated from Level B and $400 \mathrm{~m}^{2}$ from Level II. Thus, the chronological study is based on these levels. However, the earliest Aceramic Neolithic Levels G, F and $\mathrm{E}$ and the Ceramic Neolithic level, Layer 2, have also been considered in order to follow the development of the bone-tool industry throughout the site's occupation. A total of 1,255 of the 2,317 excavated bone artifacts have been taken into account (table 3).

\section{THE BONE-TOOL INDUSTRY OF THE KHIROKITIA ACERAMIC NEOLITHIC}

\section{RAW MATERIAL}

One of the main features of this industry is the considerable exploitation of fallow deer (Dama mesopotamica) long bones, particularly metapodials (63\% of identified long bones) (fig. 2); the use of fallow deer antler is very rare (4\%). The selection of the metapodials as raw material for manufacturing

12. DikAios and StewART, 1962; LE BRUN et DAUNE-LE BRUN, 2003. 
tools appears throughout the Aceramic Neolithic occupation. This choice is not surprising since the bone presents several particularities that are suitable to its transformation: a rectilinear morphology, a dense structure and a rounded distal end, which is useful to hold the tool in the hand. For those reasons, metapodials were widely used during the Neolithic in many cultural contexts.

Fallow deer was largely exploited from Level G to Level I (fig. 3). This is very interesting, since a different pattern is observed in the faunal remains. Indeed, the proportion of fallow deer decreases from 39\% in Level G to $10 \%$ in Level I, while the proportion of caprines increases in the same levels, from $35 \%$ to $81 \%^{13}$ (fig. 4). The decrease of fallow deer in the fauna does not seem to be reflected in the selection of this species for tool production. No arguments are put forward here to explain the importance of fallow deer as raw material, but it seems that fallow deer played a major role in the economy of Cypriot communities..$^{14}$ On the basis of the data currently available, either technical or symbolic hypotheses could explain this choice. Indeed, the bones of fallow deer and caprines are almost equal in size ${ }^{15}$ and the status of this species-wild or domestic - is a matter of debate. As S.J.M. Davis ${ }^{16}$ showed, the proportion of females and young is quite high among the deer remains at Khirokitia, which suggests a possible semi-captivity of these animals. However, as argued by J.-D. Vigne, ${ }^{17}$ the opening of the landscape that occurred between Levels $\mathrm{F}$ and $\mathrm{B}$, could have divided the population of fallow deer into two groups, a small group of males and a larger group of females and young, which are probably easier to hunt. That may explain the frequency of females and young in the Khirokitia faunal remains.

\section{TYPES OF TOOLS AND MANUFACTURING TECHNIQUES}

The two main categories of tools found throughout the Aceramic Neolithic occupation are points and needles. Chronological changes in the morphology of the tools are more noticeable. The typology of Khirokitia bone tools was established according to the way bones were broken into blanks, and to the presence or transformation of anatomical characters. With the exception of tools made from whole bones (for which no segmentation

13. DAVIS, 2003: 262, fig. 6 .

14. RONEN, 1995: 187.

15. DAVIS, 1984: tables 5-6 and tables 10-11, 1994: 308 and 2003: 264.

16. Ibid., 2003.

17. VIGNE et al., 2003: 245 .

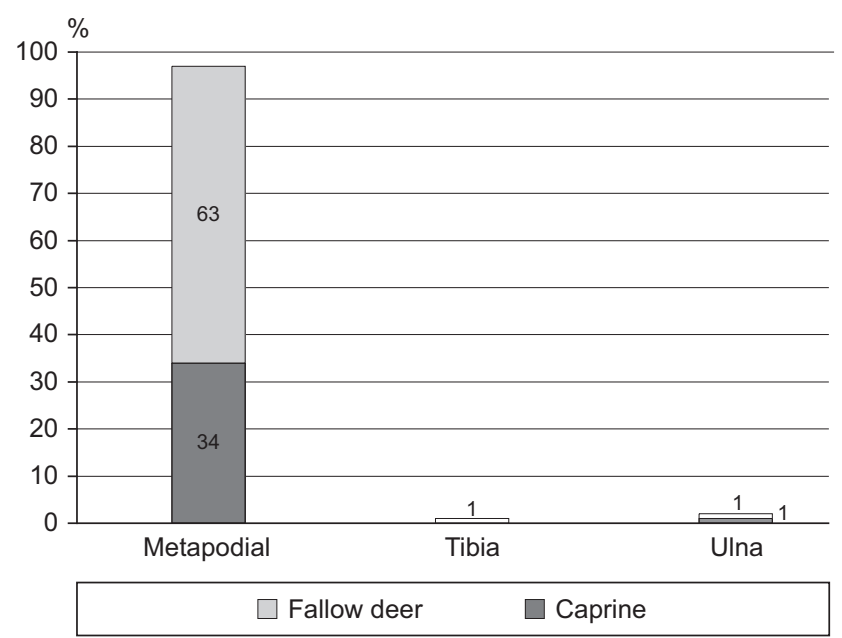

Fig. 2 - The frequency of caprine and fallow deer long bones exploited for bone tools production $(n=289)$.

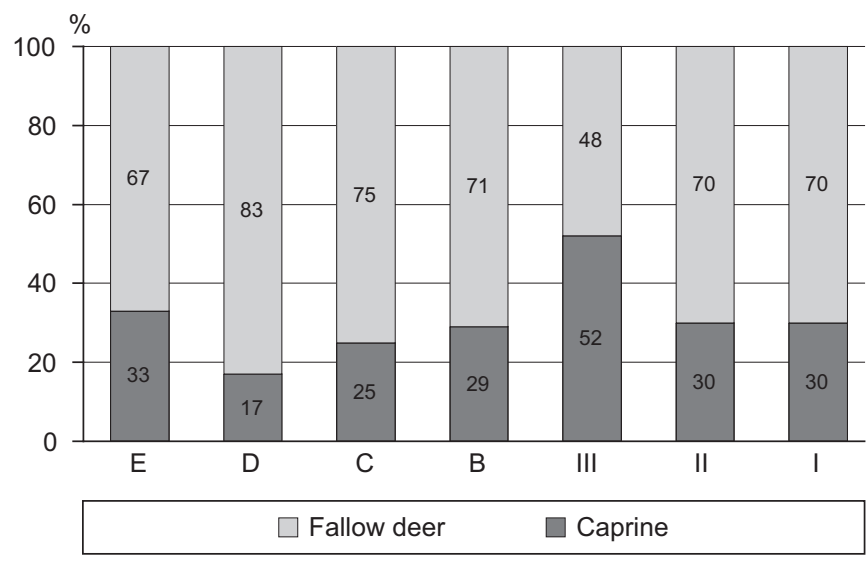

Fig. 3 - The frequency of caprine and fallow deer exploited for bone tools production $(n=327)$.

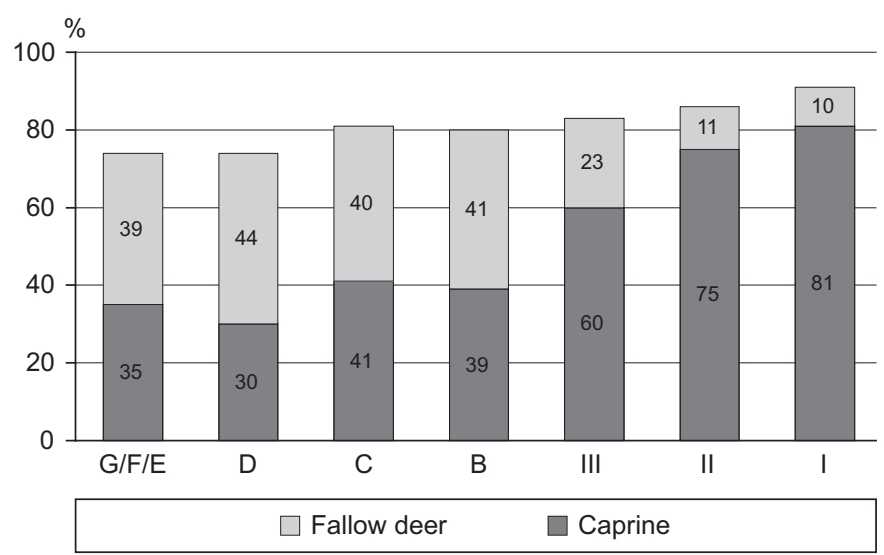

Fig. 4 - The frequency of caprine and fallow deer bones in the Khirokitia faunal assemblage (from DAVIS, 2003: fig. 6). 

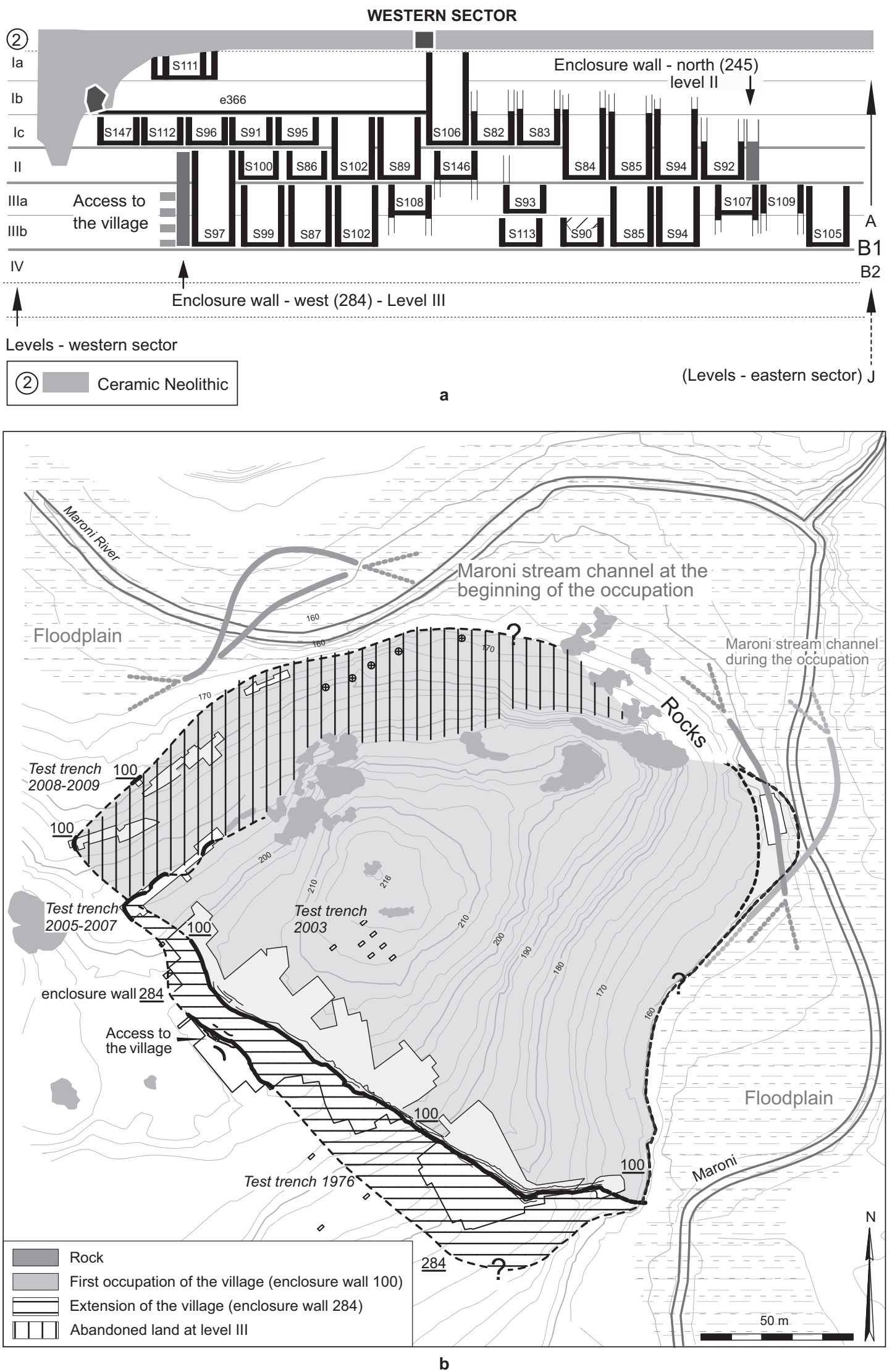

Paléorient, vol. 35.2, p. 113-123 @ CNRS ÉDITIONS 2009 


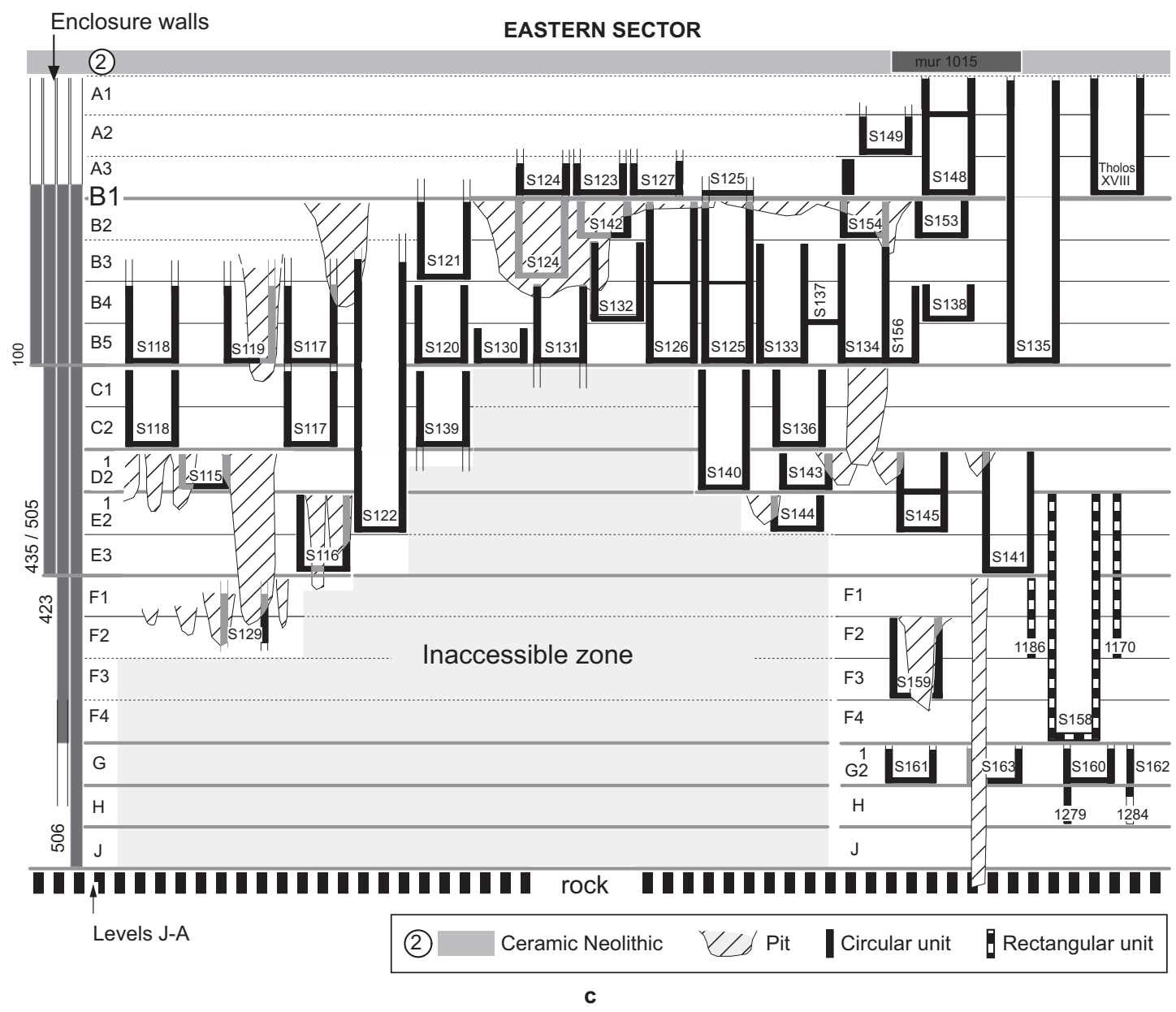

Fig. 5 - a, Stratigraphy of the western sector; $\boldsymbol{b}$, plan of the village of Khirokitia; $\boldsymbol{c}$, stratigraphy of the eastern sector.

was applied), longitudinal and transverse blanks were distinguished. Tools made from splinters (that is made on longitudinal segments of long bone without epiphyses) are predominant in Levels F, E and B, and decrease in Level II (fig. 6). Tools made on longitudinal blanks of long bone with the epiphysis preserved (obtained by indirect percussion, grooving, or by a combination of both techniques), appear in Level B and then increase up to Level II. Lastly, tools made from whole bones (such as those made from ulnae) are present only in Levels F and E. These results show that during the earliest Aceramic Neolithic levels studied, expedient techniques dominate, and over time they are replaced by more elaborate techniques, such as indirect percussion, which imply more diversified tools and a specific knowledge to put to better use the whole material (fig. 7). The desire to develop a morphological or metrical stan- dard, and an assertion of Aceramic Neolithic technical knowledge are probable reasons for this change.

All needles found in the Aceramic Neolithic levels have a rectilinear head. In the course of time, this type decreases significantly while other types of needle heads appear (fig. 8). Functional parameters do not seem to be the cause of this change; the use-wear analysis performed on Khirokitia needles shows that the same wear patterns, mostly attributed to working plant fibres, are observed on different types of needle heads. ${ }^{18}$ However, could needle variation in head morphology be related to individual variability (a greater number of artisan made needles) or to the identity of the artisan?

18. LEGRAND, 2007 and 2008. 

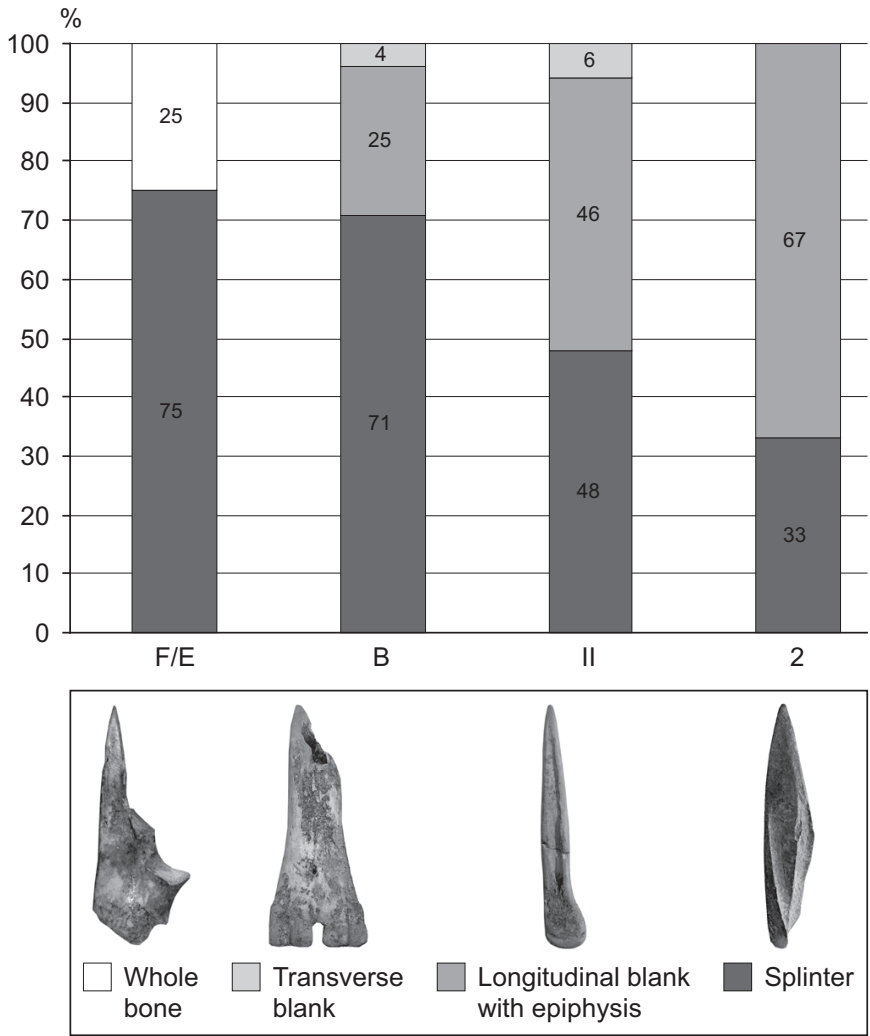

Fig. 6 - The frequency of types of blanks used for bone tools manufacture $(n=277)$.

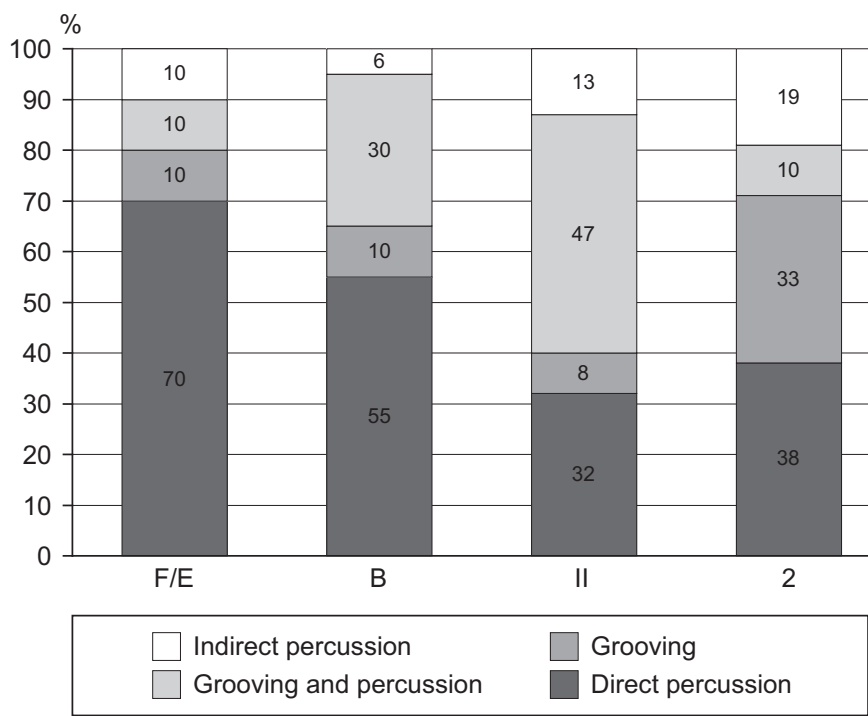

Fig. 7 - The frequency of manufacturing techniques used for bone tools production $(n=232)$.

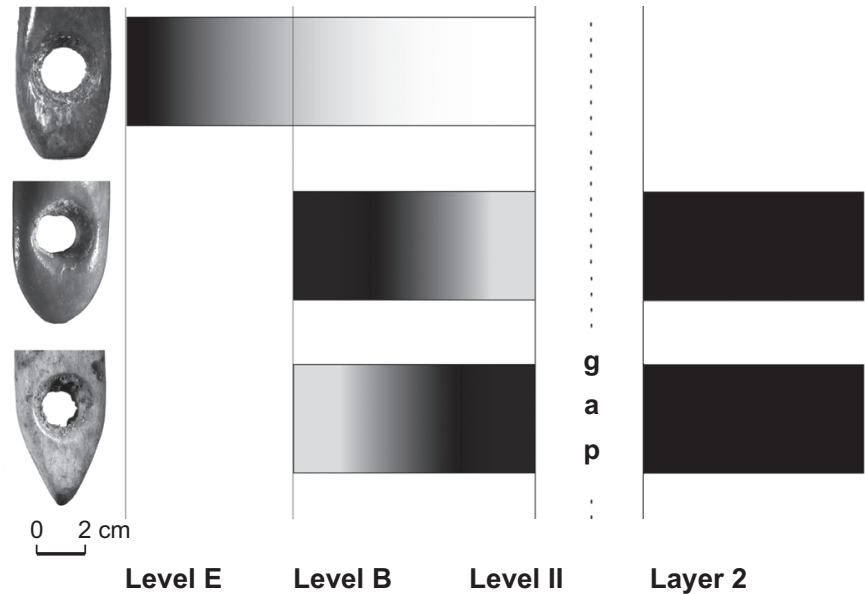

Fig. 8 - Chronological evolution of needles head shape.

\section{TECHNICAL CONTINUITY AS A MARKER OF TRADITION BETWEEN ACERAMIC AND CERAMIC NEOLITHIC BONE-TOOL INDUSTRIES}

\section{RAW MATERIAL}

What happens during the Ceramic Neolithic occupation? Few changes were noticed between both occupations concerning the raw material and species exploited; bone is still the main raw material used (96\%). More interesting however is the preference for fallow deer metapodials as raw material. This remains strong during the Ceramic Neolithic occupation $(60 \%$ of the exploited species are fallow deer, $40 \%$ are caprines). This choice may reflect the existence of a strong tradition in the selection of species for bone tool manufacturing, which continues during the Neolithic in Cyprus. At Cape AndreasKastros, fallow deer is also the most commonly exploited species for bone-tool production. ${ }^{19}$ If we compare it to the PPNB succession in the Levant, where fallow deer bones are used far less than gazelle bones, ${ }^{20}$ we can suggest that this preference could be specific to Cypriot Neolithic settlements.

19. LE BRUN, 1981; LEGRAND, 2007.

20. LE DOSSEUR, 2006 and 2008. 

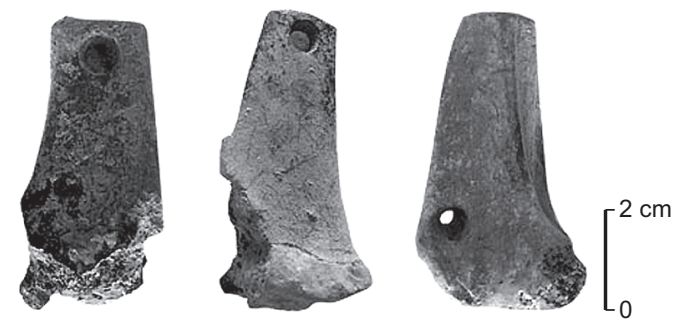

Fig. 9 - Object made from perforated proximal tibiae characteristic of the Layer 2.

\section{TYPES OF TOOLS AND MANUFACTURING TECHNIQUES}

Pointed tools are still predominant in Layer 2. The tendency observed in types of blanks used to manufacture tools in the Aceramic Neolithic occupation is confirmed in Layer 2. Indeed, the use of splinters continues to decrease in this layer, and the longitudinal blanks of long bones with epiphyses become predominant. Furthermore, the use of grooving and indirect percussion increase in Layer 2 (33\% and 19\% respectively).

The same phenomenon is observed if we consider needles. Needles with a rounded or ogival head, which are widely manufactured from Level III, are still present in Layer 2, while needles with a rectilinear head disappear at the end of the Aceramic Neolithic occupation and are absent from Layer 2. Thus, the most common shapes within the latest Aceramic Neolithic levels continue to be manufactured during the Ceramic Neolithic. This continuity in tool morphology and manufacturing techniques could be interpreted as a reinforcement of a technical tradition that began in the Aceramic Neolithic at Khirokitia. Despite this continuity, we found a new type of object made from perforated proximal tibiae in Layer 2 (fig. 9). These artifacts are absent from the Aceramic Neolithic levels and could be, if they spread to other Cypriot industries, characteristic of bone tool production during the Ceramic Neolithic period.

\section{CONCLUSION}

If we examine the main characteristics of the Khirokitia bone-tool industry in a chronological view, we can see that the main features that began in the Aceramic Neolithic occupation continue during the Ceramic Neolithic occupation, despite some technical changes and morphological innovations, which could possibly be attributed to a new social and cultural context (fig. 10). Some technical behaviours in raw material exploitation, in tool morphology and in the use of manufacturing techniques have been observed throughout the Khirokitia occupation. These first results have to be considered as preliminary, since this research is only based on one site, and there are far fewer of bone tools coming from the Ceramic Neolithic occupation of Khirokitia than from the Aceramic Neolithic levels. In conclusion, the continuity between Aceramic and Ceramic Neolithic periods observed in the bone-tool industry, but also in the exploitation of animal species and plants, could be another argument in support of a local evolution to explain the origin of the Ceramic Neolithic period in Cyprus.

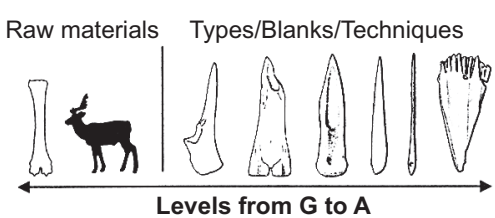

Raw materials Types/Blanks/Techniques

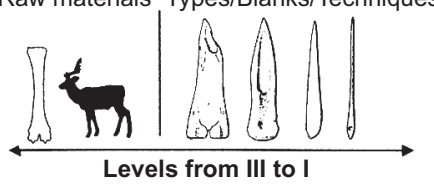

ACERAMIC NEOLITHIC
Raw materials Types/Blanks/Techniques

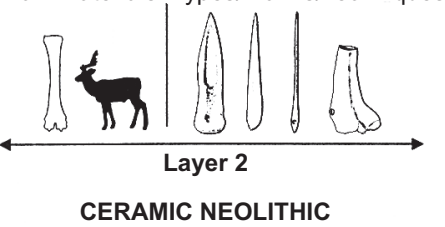

Fig. 10 - Chronological evolution of the main Khirokitia bone industry features. 


\section{ACKNOWLEDGMENTS}

I am very grateful to A. Le Brun and O. Daune-Le Brun for giving me the opportunity to study the Khirokitia bone tools assemblage. I also thank S.J.M. Davis for his help with the identification of bones and J. Lewis for revising the English text.
Alexandra LEGRAND-PINEAU

CNRS-UMR 7055 Préhistoire et technologie

Maison René-Ginouvès

21, allée de l'Université

92023 Nanterre Cedex - FRANCE

alexandra.legrand@mae.u-paris10.fr

\section{BIBLIOGRAPHY}

ClARKe J.

2001 Style and Society in Ceramic Neolithic Cyprus. Levant 33: 65-80.

ClARKE J., MCCARTNEY C. and WASSE A.

2007 On the Margins of Southwest Asia. Cyprus during the 6th to 4th Millennia BC. Oxford: Oxbow Books.

\section{DAVIS S.J.M.}

1984 Khirokitia and its Mammal Remains, a Neolithic Noah's Ark. In : LE BRUN A. (éd.), Fouilles récentes à Khirokitia (Chypre) 1977-1981. Études néolithiques: 147-162. Paris: Éditions Recherche sur les Civilisations (Mémoire 41).

1994 Even more Bones from Khirokitia: The 1988-1991 Excavations. In: LE BRUN A. (éd.), Fouilles récentes à Khirokitia (Chypre) 1988-1991. Études néolithiques: 305-334. Paris: Éditions Recherche sur les Civilisations.

2003 The Zoo-Archaeology of Khirokitia (Neolithic Cyprus), including a View from the Mainland. In : GUILAINE J. et LE BRUN A. (éd.), Le Néolithique de Chypre. Actes du Colloque international organisé par le Département des Antiquités de Chypre et l'École française d'Athènes, Nicosie 17-19 mai 2001: 253-268. Athènes: École française d'Athènes (Bulletin de correspondance hellénique S43).

DIKAIOS P.

1961 Sotira. Philadelphia: The University Museum, University of Pennsylvania.

DIKAIOS P. and STEWART J.R.

1962 The Swedish Cyprus Expedition. The Stone Age and the Early Bronze Age in Cyprus, vol. IV, Part la. Lund: The Swedish Cyprus Expedition.

GOMEZ B. and PEASE P.

1992 Early Holocene Cypriot Coastal Palaeography. Report of the Department of Antiquities: 1-8.

HELD S.O.

1992 Pleistocene Fauna and Holocene Humans: A Gazetteer of Paleontological and Early Archaeological Sites on Cyprus. Jonsered: Paul Aströms Förlag (Studies in Mediterranean Archaeology XCV).

1993 Insularity as a Modifier of Culture Change: The Case of Prehistoric Cyprus. Bulletin of the American Schools of Oriental Research 292: 25-33.

HESSE A. et RENIMEL S.

1978 Reconnaissance des limites du site néolithique de Khirokitia (Chypre) d'après les distributions superficielles des vestiges et la résistivité du sol. Revue d'archéométrie 2: 5-18.
KARAGEORGHIS V.

$1990 \quad$ Les anciens chypriotes. Paris : Éditions Errance.

KNAPP A.B., HELD O. and MANNING S.W.

1994 The Prehistory of Cyprus: Problems and Prospects. Journal of World Prehistory 8,4: 377-453.

LE BRUN A.

1981 Un site néolithique précéramique en Chypre: Cap AndreasKastros. Paris: Éditions ADPF (Recherche sur les grandes civilisations, Mémoire 5).

1984 Fouilles récentes à Khirokitia (Chypre) 1977-1981. Études néolithiques. Paris: Éditions Recherche sur les Civilisations (Mémoire 41).

1989 Fouilles récentes à Khirokitia (Chypre) 1983-1986. Études néolithiques. Paris: Éditions Recherche sur les Civilisations (Mémoire 81).

1994 Fouilles récentes à Khirokitia (Chypre) 1988-1991. Études néolithiques. Paris: Éditions Recherche sur les Civilisations.

1996 L'économie de Chypre au Néolithique. In: KARAGEORGHIS V. and MICHAELIDES D. (eds.), The Development of the Cypriot Economy from the Prehistoric Period to the Present Day: 1-15. Nicosia: The University of Cyprus and Bank of Cyprus.

2000 À propos des sites néolithiques chypriotes à limites aménagées. In: OANNIDES G.C. and HADJISTYLLIS S. (eds.), Acts of the Third International Congress of Cypriot studies, 16-20 April 1996: 203-217. Nicosia: Society of Cypriot Studies.

LE BRUN A. et DAUNE-LE BRUN O.

2003 Deux aspects du Néolithique pré-céramique récent de Chypre: Khirokitia et Cap Andreas-Kastros. In: GuILAINE J. et LE BRUn A. (éd.), Le Néolithique de Chypre. Actes du Colloque international organisé par le Département des Antiquités de Chypre et l'École française d'Athènes, Nicosie 17-19 mai 2001 : 45-59. Athènes: École française d'Athènes (Bulletin de correspondance hellénique $\mathrm{S} 43$ ).

LE DOSSEUR G.

2006 La néolithisation au Levant Sud à travers l'exploitation des matières osseuses. Étude techno-économique de onze séries d'industries osseuses du Natoufien au PPNB récent. Thèse de doctorat non publiée. Paris : université de Paris-I.

2008 La place de l'industrie osseuse dans la néolithisation au Levant Sud. Paléorient 34,1 : 59-89.

LEGGE A.J.

1982 The Vertebrate Fauna. In: PELTENBURG E. (ed.), Vrysi. A Subterranean Settlement in Cyprus. Excavation at Prehistoric Ayios Epiktitos 1969-1973: 76-87. Warminster: Aris and Philipps Ltd. 


\section{LEGRAND A.}

$2007 \quad$ Fabrication et utilisation de l'outillage en matières osseuses du Néolithique de Chypre. Khirokitia et Cap Andreas-Kastros. Oxford (BAR Int. Ser. 1678).

2008 Neolithic Bone Needles and Vegetal Fibres Working: Experimentation and Use-Wear Analysis. In: LONGO L. and SKAKUN N. (eds.), Prehistoric Technology 40 Years Later: Functional Studies and the Russian Legacy. Proceedings of the International Congress, Verona (Italy), 20-23 April 2005: 445-450. Oxford (BAR Int. Ser. 1783).

\section{LEHAVY Y.M}

1989 Exacavations at Dhali-Agridhi: 1972, 1974, 1976. In: STAGER L.E. and WALKER A. (eds.), American Expedition to Idalion, Cyprus, 1973-1980: 203-243. Chicago: The Oriental Institute.

PELTENBURG E.

1979 Troulli reconsidered. In: KARAGEORGHIS V. (ed.), Studies in honour of Porphyrios Dikaios: 21-45. Nicosia: Lions Club of Nicosia, Zavallis Press LTD.

1982

Vrysi. A Subterranean Settlement in Cyprus. Excavation at Prehistoric Ayios Epiktitos 1969-1973. Warminster: Aris and Philipps Ltd.

Peltenburg E., Bolger D., Colledge S., Croft P., Fox S.C., Goring E., JACKSON A., LUNT D.A., MCCARTNEY C., MURRAY M.A., RIDOUTSHARPE J., THOMAS G. and WATT M.E.

2003 Lemba Archaeological Project, Cyprus Vol. II.I. The Colonisation and Settlement of Cyprus. Investigations at KissonergaMylouthkia 1976-1996. Jonsered: Paul Aströms Förlag (Studies in Mediterranean Archaeology 70,4).

RONEN A.

1995 Core, Periphery and Ideology in Aceramic Cyprus. Quatär 45,46: 177-206.

\section{ŞEVKETOĞLU M.}

$2000 \quad$ Archaeological Field Survey of the Neolithic and Chalcolithic Settlement Sites in Kyrenia District, North Cyprus. Systematic Surface Collection and the Interpretation of Artefact Scatters. Oxford (BAR Int. Ser. 834).

\section{STANLEY-PRICE N.}

1977 Colonisation and Continuity in the Early Prehistory of Cyprus. World Archaeology 9: 27-42.

1979 The Structure of Settlement at Sotira in Cyprus. Levant 11: 46-83.

TODD I.

1985 The Vasilikos Valley and the Chronology of the Neolithic/ Chalcolithic Periods in Cyprus. Report of the Department of the Antiquities: 1-15.

VIGNE J.-D., CARRÈRE I. and GUILAINE J.

2003 Unstable Status of Early Domestic Ungulates in the Near East: The Example of Shillourokambos (Cyprus, IX-VIIIth Millennia cal. BC). In: GuILAINE J. et LE BRUN A. (éd.), Le Néolithique de Chypre. Actes du Colloque international organisé par le Département des Antiquités de Chypre et l'École française d'Athènes, Nicosie 17-19 mai 2001 : 239-252. Athènes: École française d'Athènes (Bulletin de correspondance hellénique S43).

WATKINS T.

1971 Philia-Drakos. In : KARAGEORGHIS V. (éd.), Chronique des fouilles et découvertes archéologiques à Chypre en 1970. Bulletin de correspondance hellénique 95,1: 371-374.

1973 Some Problems of the Neolithic and Chalcolithic Period in Cyprus. Report of the Department of the Antiquities: 34-61. 


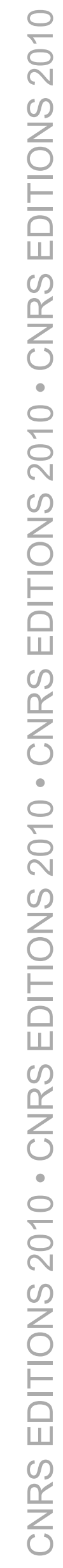

